\title{
ACTIONS THAT COMBAT THE DISRUPTION OF THE MORAL AND SOCIAL CODE WITH THE PURPOSE OF FAVORITISM
}

\author{
Sergio Armando PRADO de TOLEDO \\ Justice of the São Paulo State Court of Justice \\ Director of São Paulo School of Judges
}

\begin{abstract}
Currently, corruption has been so generalized and sophisticated that threatens to undermine the own society structure. Corruption is a problem identified in all the countries. What changes is how we deal with it. Nevertheless, why is there so much corruption? Within the group of factors, it is possible to highlight the high bureaucracy that reduces the efficiency of the public administration; the presence of a slow Judiciary Branch which is very low is terms of efficiency, when reprimanding illicit practices that incite everything ending up in pizza (this sentence was literally translated from Portuguese, it does not exist in English, but it means that impunity prevails in Brazil.); the existence of a corporatist sense among the Administration industries in the public sector in relation to the private sector and so facilitating corruption.

The penalty for corruption should be constrained to mechanisms that allow the system of criminal justice to carry out actions of arrest, prosecution, penalty and repair to the country. Combating corruption complies with the republican ideal for the reduction of costs in Brazil. Moralizing the public-private relations offers juridical security to the market. The fact that some countries, especially Brazil, are seriously combating against corruption brings hope, with an eye on a more rigid legislation and less bureaucratic as well, with the end of the corporatist sense and the equivalence of salaries between the public and private sector. We shall provide effective criminal, administrative and civil penalties of inhibiting nature for future action; we shall provide cooperation between the law applicator and the private companies; we shall prevent the conflict of interests; we shall forbid the existence of "black fund" at the companies and we shall encouraged the relief or reduction of taxes to expenses considered as bribery or other conducts related.
\end{abstract}

Keywords: corruption-Brazil-countries-Judiciary Branch-bureaucratic

Once, Nicolo Machiavelli said he saw corruption as tuberculosis: "... in the beginning it is easy to cure and hard to diagnose. As time goes by, not being acknowledged nor even treated, it becomes easily diagnosed but difficultly cured". Currently, corruption has been so generalized and sophisticated that threatens to undermine the own society structure. In some countries, it is almost impossible to get something without bribery. When you bribe the right person, it is possible to pass the exams, get the driver's license or even the contract of services rendered. We shall be indignant and try to root out corruption, by monitoring, accompanying and acting with strictness, so this disease does not affect the good man. 
Prado de Toledo, S.A., (2015)

Actions that combat the disruption of the moral and social code with the purpose of favoritism

Last month, Chile has announced a tough plan of measures against corruption for private and public industries, including the elaboration of a new constitution. In order to reverse the culture of corruption, Chile has decreased the government machinery. Apparently, it was sustained that the administrations get better with a smaller structure.

In February, the European Commission disclosed the first report about corruption in the EU members. The most frightening data affects all the countries from the European Union whose cost is estimated around 120 billion of Euros a year.

From November 2005 to September 2014, the U.S. Department of Justice, equivalent to the Ministry of Justice of Brazil, started 237 corruption cases exclusively related to the industrial-military complex from the largest economy in the world.

According to the rate which appears on TV da Camara do Brasil (a Brazilian public television network responsible for broadcasting activities from the Brazilian Chamber of Deputies), there are 355 law projects about corruption, which is an initiative of some deputies and 173 senators, involving a total of 528 approaches. Maybe all this legal material reinforces the preoccupation of Public Prosecutor, Roberto Levianu, by stating in a blog that in Brazil there are still people who use airplanes to watch soccer games and ask extension of flight tickets to their spouses, by using the government machinery for private purposes.

Corruption is a problem identified in all the countries. What changes is how we deal with it.

Nevertheless, why is there so much corruption?

Within the group of factors, it is possible to highlight the high bureaucracy that reduces the efficiency of the public administration; the presence of a slow Judiciary Branch which is very low is terms of efficiency, when reprimanding illicit practices that incite everything ending up in pizza (this sentence was literally translated from Portuguese, it does not exist in English, but it means that impunity prevails in Brazil.); the existence of a corporatist sense among the Administration industries in the public sector in relation to the private sector and so facilitating corruption.

The famous Operação Lava Jato (an investigation being carried out by the Federal Police of Brazil) has already served many prison warrants (and many people are still in jail), there were many searches and seizures and also many criminal deed were filed, 50 corruption suspects are still being investigated and millions of reais have been repatriated.

When the Judiciary Branch adopts the strategy of efficiency with practices equivalent to the repression of criminal conducts, what we see is the protection of all and any public and private entity.

In an interview with the newspaper Estado de São Paulo, Dealtan Martinazzo Dallagnol, Public Prosecutor and coordinator of the huge investigation, together with the Federal Police, who crumbled the cartel of contractors infiltrated in 
Prado de Toledo, S.A., (2015)

Actions that combat the disruption of the moral and social code with the purpose of favoritism

Petrobras for frauds in billionaire biddings and the payment of briberies to at least 50 politicians, stated that corruption should be punished in a tougher way than in relation to a murder, because it kills many people. It even steals schools, the water piped, the medicines and safety of millions of Brazilians.

For this reason, the penalty for corruption should be constrained to mechanisms that allow the system of criminal justice to carry out actions of arrest, prosecution, penalty and repair to the country.

Combating corruption complies with the republican ideal for the reduction of costs in Brazil. Moralizing the public-private relations offers juridical security to the market.

The president of Brazil and the Minister of Justice, José Eduardo Cardozo, have announced a package of measures against corruption, to which we highlight many legal advances:

1 - Criminalization of the election black fund and money laundering for electoral purposes. Currently, this practice is considered as a misdemeanor, that is, a lighter crime punished with a softer penalty.

2 - Seizing of properties in cases that clearly shows incompatibility with the income, even if there is coordination. This shall demand a change at the Constitution (at the part regarding property right) and a law project in order to detail the new rules.

3 - Possibility of bidding of properties seized even if before a final decision of the Justice. If the defendant is acquitted, this one may recover the values obtained with the sales.

4 - Extension of the Clean Slate criteria for all the people who exercise commissioned posts in all the spheres.

5 - Penalty for public representatives who failed to prove the origin of their assets and resources.

6 - Regulation the anticorruption law, approved at the last legislature in order to punish the corrupt.

7 - Creation of a work group in order to debate ways of speeding the cross-border legal procedures regarding corruption.

Combating corruption meets the republican ideal and contributes for the cost reduction in Brazil. The moralization of the public-private relations brings legal certainty to the market.

Of course, the production the results expected depends on limitations. On one hand, this measure may be hopeful. On the other hand, it triggers discussions. It happens because its application may paradoxically generate not so much efficient results.

See that the leniency agreements shall be of the exclusive competence of the Comptroller General of the Union (CGU) regarding the Federal Executive. 
Prado de Toledo, S.A., (2015)

Actions that combat the disruption of the moral and social code with the purpose of favoritism

The leniency agreements resemble the plea bargain agreements and set forth that legal entities who assume irregular acts and collaborate with investigations may have penalty reduction.

Federal Public Minister sustains that the leniency agreements may be "harmful" to the Lava Jato investigations, in which many defendants have been bargaining pleas.

We believe this topic deserves more legal further development to questions related to criminal investigations.

It is the culture of impunity that shall overcome corruption.

In this context, our big challenge is to defend the excellence and virtue as prevailing criteria against bad social conduct.

Therefore, we understand that each country must introduce in its legal order criminal offences which broaden not only basic ways of corruption but also bribery and embezzlement of public funds and acts which contribute to corruption, such as obstruction of justice, traffic of influence and laundering of resources coming from corruption.

The fact that some countries, especially Brazil, are seriously combating against corruption brings hope, with an eye on a more rigid legislation and less bureaucratic as well, with the end of the corporatist sense and the equivalence of salaries between the public and private sector. We shall provide effective criminal, administrative and civil penalties of inhibiting nature for future action; we shall provide cooperation between the law applicator and the private companies; we shall prevent the conflict of interests; we shall forbid the existence of "black fund" at the companies and we shall encouraged the relief or reduction of taxes to expenses considered as bribery or other conducts related.

We shall not be sorry about the corruption news that is widespread throughout the country, on the contrary, we shall applause the press liberty, we shall worship the protection fostered by the Public Ministry, we shall congratulate the efficient actions of Police, either state or federal, we shall also check the action of the Judiciary Branch, as well as the application of our laws and also foster the spreading that corruption shall be combated by everyone. 